\title{
Geriatric gynecology: need and spectrum
}

\section{Mridula Singh*, Sudha Chourasia}

\begin{abstract}
Department of Obstetrics and Gynecology, Atal Bihari Vajpayee Government Medical College, Vidisha, Madhya
\end{abstract} Pradesh, India

Received: 11 April 2020

Accepted: 04 May 2020

*Correspondence:

Dr. Mridula Singh,

E-mail: dr_mridula@ymail.com

Copyright: (c) the author(s), publisher and licensee Medip Academy. This is an open-access article distributed under the terms of the Creative Commons Attribution Non-Commercial License, which permits unrestricted non-commercial use, distribution, and reproduction in any medium, provided the original work is properly cited.

\section{ABSTRACT}

Background: Geriatric gynaecology deals with gynaecological pathologies essential in post-menopausal women aged 65 years and above. The spectrum of geriatric gynaecological disorders in India differs from those in developed countries as there are no effective screening program for early detection of cancer and the burden of ignorance and taboos. In this study we aim to find the spectrum of gynaecological disorders in geriatric women and establish the need of dedicated geriatric unit.

Methods: A cross-sectional comparative study was conducted on menopausal women of age 45 years or above who attended gynecology OPD for general counselling about menopause or treatment of menopausal problems over the period of 6 months duration. All these menopausal women attending OPD during this interval were evaluated on the basis of pretested questionnaire.

Results: Out of 234 post-menopausal women who entered the study, 29\% women belong to geriatric group. Postmenopausal bleeding due to both malignant and benign causes and pelvic organ prolapse are the major problems in geriatric women whereas somatic complaints like flushing, night sweats are more common in younger menopausal women.

Conclusions: Where the medical science has successfully increased the life expectancy, focused approach to geriatric gynecology around us is our responsibility, where female still hesitate to come out. The need for dedicated geriatric gynecology unit in India on urgent basis is emphasized by this study wherein cancers can be screened in early stage and severe lifestyle hampering conditions like pelvic organ prolapse can be treated timely.

Keywords: Geriatric, Geriatric unit, Gynecology, Menopause, Menopausal symptoms, Post-menopausal

\section{INTRODUCTION}

Geriatric gynaecology deals with gynaecological pathologies essential in post-menopausal women aged 65 years and above. 25 million women are predicted to enter the menopausal period worldwide each year. Based on WHO in Asia in 2025, the amount of advanced age women would increase from 107 million to 373 million due to increased life expectancy and lifestyle changes like more active post-menopausal life. ${ }^{1}$ The society which was pyramidal till $20^{\text {th }}$ century is now on the verge of becoming a rectangular society. ${ }^{2}$ The number of women aged 60 years has grown from $5.4 \%$ to $7.8 \%$ in $2001 .^{3}$
Geriatric population is estimated to be $12.4 \%$ of population by the year $2026 .{ }^{4}$ The spectrum of geriatric gynaecological disorders in India differs from those in developed countries as there are no effective screening programme for early detection of cancer, hardly any dedicated geriatric unit and the burden of ignorance and taboos.

The aim of this study is to assess the various types of gynaecological problems faced by older women in Central India and to emphasize the need of dedicated geriatric unit to meet the special need of this subset of population. 


\section{Objective of the study}

- To find the spectrum of gynaecological disorders in geriatric women.

- To compare prevalence and discrepancies of gynaecological complaints between geriatric women and other menopausal women.

\section{METHODS}

Cross-sectional comparative study conducted from $1^{\text {st }}$ January 2019 to $30^{\text {th }}$ June 2019 at Atal Bihari Vajpayee Government Medical College, Vidisha, Madhya Pradesh, India. Menopausal women of age 45 years or above who attended gynecology OPD for general counselling about menopause or treatment of menopausal problems were evaluated on the basis of pretested questionnaire.

\section{Inclusion criteria}

- All post-menopausal women >45 years attending gynecological OPD

- Women who volunteered to participate

- Women who had no previous uterine/ovarian extraction surgery.

\section{Exclusion criteria}

- Women attending OPD for non-gynecological problems

- Women not willing to participate.

\section{Statistical analysis}

Data was entered in excel sheet and was calculated for frequency and percentage. Association between the variables was established using EPI info software using chi-square test. p-value $<0.05$ was considered to be a significant difference and $<0.005$ was considered to be highly significant.

\section{RESULTS}

Out of 234 post-menopausal women, 68 women i.e. $29 \%$ were of geriatric age group (65years age) whereas 166 women i.e.71\% were of other age group (45-65 years) (Table 1).

Table 1: Distribution according to age.

\begin{tabular}{|lll|}
\hline Age (years) & Frequency (n) & Percentage \\
\hline $45-65$ & 166 & $71 \%$ \\
\hline$>65$ & 68 & $29 \%$ \\
\hline Total & 234 & $100 \%$ \\
\hline
\end{tabular}

Socio economic status of women of geriatric and other menopausal age group had no significant difference (Chi sq. 7.34, p value 0.1149). Majority of women in both the groups belonged to Class IV and V of BG Prasad scale with 23 women (33.8\%) and 27 women (39.7\%) respectively from geriatric age group and 68 women $(40.9 \%)$ and 70 women $(47.16 \%)$ respectively from menopausal women of other age group (Table 2). Illiterate or $<5^{\text {th }}$ std education comprised of $(38.2 \%)$ geriatric and $(70.5 \%)$ menopausal women of other age group. This difference was significant (Chi sq. 23.46, p value $<0.05$ ) suggesting that geriatric female who were less educated seek less health care (Table 3). More women from urban setup seek healthcare facility which was 21 women $(30.9 \%)$ compared to 23 women $(13.85 \%)$ of women from other age group. This difference was significant (Chi sq. 9.16, p value <0.05) (Table 4).

Table 2: Distribution according to socio economic status.

\begin{tabular}{|lllll|}
\hline BG Prasad Scale & Geriatric (n) & Percentage & Others (n) & Percentage \\
\hline I & 2 & $2.9 \%$ & 1 & $0.6 \%$ \\
\hline II & 6 & $8.8 \%$ & 4 & $2.4 \%$ \\
\hline III & 10 & $14.7 \%$ & 23 & $13.8 \%$ \\
\hline IV & 23 & $33.8 \%$ & 68 & $40.9 \%$ \\
\hline V & 27 & $39.7 \%$ & 70 & $42.16 \%$ \\
\hline Total & 68 & $100 \%$ & 166 & $100 \%$ \\
\hline
\end{tabular}

Table 3: Distribution according to education level.

\begin{tabular}{|lllll|}
\hline Education & Geriatric & Percentage & Others & Percentage \\
\hline Illiterate and $<5^{\text {th }}$ & 26 & $38.2 \%$ & 117 & $70.5 \%$ \\
\hline $5^{\text {th }}$ to $12^{\text {th }}$ & 37 & $54.4 \%$ & 47 & $28.3 \%$ \\
\hline $12^{\text {th }}$ pass & 4 & $5.9 \%$ & 0 & - \\
\hline Graduate/ PG & 1 & $1.4 \%$ & 2 & $1.2 \%$ \\
\hline Total & 68 & $100 \%$ & 166 & $100 \%$ \\
\hline
\end{tabular}


Table 4: Distribution according to living area.

\begin{tabular}{|c|c|c|c|c|}
\hline & $\begin{array}{l}\text { Geriatric } \\
\text { (n) }\end{array}$ & Percentage & $\begin{array}{l}\text { Others } \\
\text { (n) }\end{array}$ & Percentage \\
\hline Rural & 47 & $69.1 \%$ & 143 & $86.15 \%$ \\
\hline Urban & 21 & $30.9 \%$ & 23 & $13.85 \%$ \\
\hline Total & 68 & $100 \%$ & 166 & $100 \%$ \\
\hline
\end{tabular}

Table 5: Distribution according to parity.

\begin{tabular}{|lllll|}
\hline Parity & $\begin{array}{l}\text { Geriatric } \\
\text { (n) }\end{array}$ & Percentage & $\begin{array}{l}\text { Others } \\
\text { (n) }\end{array}$ & Percentage \\
\hline Nulli & 1 & $1.5 \%$ & 10 & $6 \%$ \\
\hline $1-3$ & 36 & $53 \%$ & 49 & $30 \%$ \\
\hline$>=4$ & 31 & $45.5 \%$ & 107 & $64 \%$ \\
\hline Total & 68 & $100 \%$ & 166 & $100 \%$ \\
\hline
\end{tabular}

Geriatric women who turned to OPD has a smaller number of children as they were motivated to provide quality life for themselves and their family. 37 geriatric women $(54.5 \%)$ has $<=3$ children whereas only $59(36 \%)$ women of other age group has $<=3$ children. This difference was significant (Chi sq. 12.33, p value 0.0021 ) (Table 5).

Post-menopausal bleeding due to both malignant $(n=15$, $22 \%)$ and benign $(n=24,35 \%)$ causes and pelvic organ prolapse $(n=22,32 \%)$ are the major problems in geriatric women whereas somatic complaints $(n=38,22.9 \%)$ like flushing, night sweats are more common in younger menopausal women (Table 6). Adnexal mass, if malignant $(n=6,8.8 \%)$ are significantly more common in geriatric women whereas benign $(n=18,10.8 \%)$ ones are more prevalent in younger menopausal women (Table 6). Urogenital and psychological complaints had similar incidence in both the groups and difference was not significant with $\mathrm{p}$ value of 0.107 and 0.45 respectively (Table 6).

Table 6: Spectrum of gynaecological morbidities.

\begin{tabular}{|c|c|c|c|c|c|c|c|}
\hline & & Geriatric (n) & Percentage & $\begin{array}{l}\text { Others } \\
\text { (n) }\end{array}$ & Percentage & $\begin{array}{l}\text { Chi- } \\
\text { sq }\end{array}$ & p value \\
\hline Pelvic organ prolapses & & 22 & $32 \%$ & 14 & $8.4 \%$ & 21.2 & $<0.005$ \\
\hline \multirow{2}{*}{$\begin{array}{l}\text { Post-menopausal } \\
\text { bleeding- malignant }\end{array}$} & Ca cervix & \multirow{2}{*}{15} & \multirow{2}{*}{$22 \%$} & \multirow{2}{*}{7} & \multirow{2}{*}{$4.2 \%$} & \multirow{2}{*}{18.02} & \multirow{2}{*}{$<0.005$} \\
\hline & Ca endometrium & & & & & & \\
\hline $\begin{array}{l}\text { Post-menopausal } \\
\text { bleeding- benign }\end{array}$ & & 24 & $35 \%$ & 31 & $18.6 \%$ & 7.411 & $<0.005$ \\
\hline $\begin{array}{l}\text { Adnexal mass- } \\
\text { malignant }\end{array}$ & & 6 & $8.8 \%$ & 1 & $0.6 \%$ & 11.23 & $<0.005$ \\
\hline Adnexal mass- benign & & 3 & $4.4 \%$ & 18 & $10.8 \%$ & 2.443 & $<0.05$ \\
\hline Urogenital & & 18 & $26.4 \%$ & 38 & $22.9 \%$ & 1.52 & 0.109 \\
\hline Somatic & & 1 & $1.4 \%$ & 38 & $22.9 \%$ & 15.94 & $<0.005$ \\
\hline Psychological & & 7 & $10.2 \%$ & 18 & $10.8 \%$ & 0.015 & 0.45 \\
\hline
\end{tabular}

\section{DISCUSSION}

In this study it has been found that somatic complaints $(\mathrm{n}=38,22.9 \%)$ like flushing, night sweats are more common in younger menopausal women. Similarly, in the study done by Siregar MFG on postmenopausal women it was found that $74 \%$ postmenopausal women came with similar complaints of Somatic disorders like hot flushes and sweating. ${ }^{5}$

The prevalence of the classic symptom of menopause, hot flushes was $76.8 \%$ in the study conducted by Sweed HS et al on Egyptian geripausal women. ${ }^{6}$ In this study $26.4 \%$ elderly menopausal women experienced urogenital complaints.

However, in the study conducted by Siregar MGF et al it was found that $58 \%$ of them had psychological issues, while $74 \%$ of them genitourinary disorders. ${ }^{5}$ Post- menopausal bleeding due to both malignant $(n=15,22 \%)$ and benign $(n=24,35 \%)$ causes in geriatric group had been observed in this study. In the study of Treloar 5$10 \%$ of women recorded a further episode of vaginal bleeding after 360 days of amenorrhea. ${ }^{7}$

Limitation of this study is a hospital-based study so the results cannot be generalized among general population

\section{CONCLUSION}

Where the medical science has successfully increased the life expectancy, focused approach to geriatric gynecology around us is our responsibility, where female still hesitate to come out surrounded by taboos and ignorance.

The need for dedicated geriatric gynecology unit in India on urgent basis is emphasized by this study wherein cancers can be screened in early stage and severe lifestyle 
hampering condition like pelvic organ prolapse can be treated timely.

\section{ACKNOWLEDGMENTS}

Authors would like to thank Dr. Akanksha Jain for statistical support and Dr. Veerendra Singh for technical guidance.

Funding: No funding sources Conflict of interest: None declared

Ethical approval: Not required

\section{REFERENCES}

1. World Health Organization. Older Women. Women and health. today's evidence tomorrows agenda. WHO; 2009:61.

2. Fritz MA, Speroff L. Menopause and the perimenopausal transition. Clinical gynaecology and endocrinology and Infertility. $8^{\text {th }}$ ed. Walter Kluwer, Lipincott Williams and Wilkins; 2010.

3. Office of Registrar general and Census Commissioner of India. New Delhi: Census of India. Ministry of Home Affairs Government of India. E
Census India. 2001. Available at: http://censusindia.gov.in/Census_Data_2001/Census _Newsletters/Newsletter_Links/eci_3.htm. Accessed on $25^{\text {th }}$ March 2020.

4. Das SK. Situation analysis of the elderly in India. A Report. Officers of Social Statistics Division, Central Statistics Office, Ministry of Statistics and Programme Implementation, Government of India, New Delhi. 2011.

5. Siregar MF. Perimenopausal and postmenopausal complaints in paramedics assessed by menopause rating scale in Indonesia. $J$ Dent Med Sci. 2014;13(12):38-42.

6. Sweed HS, Elawam AL, Nabeel AM, Mortagy AK. Postmenopausal symptoms among Egyptian geripausal women. EMHJ. 2012;18(3):213-20.

7. Treloar AE. Menstrual cyclicity and the premenopause. Maturitas. 1981;3:249-64.

Cite this article as: Singh M, Chourasia S. Geriatric gynecology - need and spectrum. Int J Reprod Contracept Obstet Gynecol 2020;9:2556-9. 